\title{
THE BIOLOGICAL ASPECTS OF MACKEREL TUNA (EUTHYNNUS AFFINIS) AND THE TECHNICAL ASPECTS OF THE MILLENNIUM GILLNET FISHING IN THE ESTUARY OF PATI REGENCY, CENTRAL JAVA, INDONESIA
}

\author{
Prasetyo Eko ${ }^{1,2 *}$, Saputra Suradi W. ${ }^{2}$, Boesono Herry ${ }^{3}$ \\ ${ }^{1}$ Master's Program in Coastal Resource Management, University of Diponegoro, Indonesia \\ ${ }^{2}$ The Fisheries Supervisor of Technical Implementation Unit, Marine and Fisheries \\ Resources Supervision Station Belawan, Medan, Indonesia \\ ${ }^{3}$ Faculty of Fisheries and Marine Sciences, University of Diponegoro, Indonesia \\ ${ }^{\star}$ E-mail: prast15381@yahoo.com
}

\begin{abstract}
Millennium gillnet is a construction development of the gillnet using a different net material which is the fiber monofilament strands. The main catch from the millennium net in Puncel is mackerel tuna. The study aims to analyze the technical aspects of millennium gillnet capture fisheries and find out the long-weight relationship and condition factors of mackerel tuna as the main catch of the millennium net. The results of the study showed that the length of mackerel tuna (Euthynnus affinis) from the millennium net catch landed in Puncel fish auction houses ranged from $33.2-52 \mathrm{~cm}$ with an average length of $43.012 \mathrm{~cm}$ FL. The pattern of fish growth is isometric with the equation $\mathrm{W}=0.1509 \mathrm{~L} 3.0513$ ( $\mathrm{r} 2=0.9898$ ) with the condition factor value $\mathrm{K}=1.613$. The catches are the target fish and they are generally caught by the snagged and gilled methods. It can be said that a millennium captures fish selectively.
\end{abstract}

\section{KEY WORDS}

Millennium gillnets, mackerel tuna, length-weight, technical asset.

Pati Regency is located in the Central Java Province, Indonesia. With an area of $1,503.68 \mathrm{~km} 2$ wide, it is astronomically located at $6^{\circ} 25^{\prime}-7^{\circ} 00^{\prime} \mathrm{SL}$ and $110^{\circ} 50 '-111^{\circ} 15^{\prime}$ EL. Pati waters are on the north coast of Java which is part of the Java Sea with a maximum depth of 70 meters. These waters have considerable potentials for fisheries; among others are capture fishery and fish farming. A few types of fish having economic value that live in these waters include round scads (Decapterus sp), Bali Sardinella (Sardinella lemuru), goldband fish (Upeneus moluccensis), mackerel tuna (Euthynnus affinis), narrow-barred Spanish mackerel (Scomberomorus commerson) and milkfish (Chanos chanos) that are harvested from the fish farming (The Central Bureau of Statistics of Pati Regency, 2018).

Capture fishery activities in Pati are dominated by small-scale fishermen, except for those based at the Fishery Port of Bajomulyo Beach. Puncel Village is one of the areas with capture fishery activities, all of which are small-scale fishermen. Most of them use gillnet fishing equipment and there are 145 units in total. The free net fishing devices are operated with outboard motors in a 1-day operation. One of the types of gillnet used is the Millennium gillnet. It is a construction development of the gillnet; the difference is in the net material that uses twisted monofilament fibers. The main catches from Millennium gillnet at Puncel are mackerel tuna and narrow-barred Spanish mackerel.

Mackerel tuna (Euthynnus affinis) dominate the type of fish caught. In international trade, it is known as the kawakawa and included in the Scombridae family. They are pelagic, schooling, fast swimmer and eater fish (chodrijah et al, 2013). They are included in a neritic tuna species spreading from the western Pacific, Japanese waters, the Philippines, the Indonesian archipelago, Australia, Indian waters to the Persian Gulf (Collette \& Nauen, 1983). Research related to the biological data of mackerel tuna had already been conducted, but only in a port base outside Pati (a port base in Pekalongan and Tegal in 2012, and ilndramayu in 2015). To date, there have not been many studies on mackerel tuna resources based in Pati. Moreover, this resource is from the catch around Pati waters; since it is only a one-day fishing operation, the fishing area is not too far away. 
The study aims to analyze the technical aspects of the millennium gillnet fishing business and to find out the relationship of length-weight and condition factors of mackerel tuna as the main catch of millennium gillnet. This information is very essential as the material for managing the millennium net fishing business to make it sustainably utilized.

\section{MATERIALS AND METHODS OF RESEARCH}

This research was conducted at Puncel fish landing site (the fish auction houses), Puncel village, Dukuh Seti District, in October - November 2018. The data collected for technical aspects included boat specifications, millennium gillnet fishing gear, methods of operation, and areas and fishing seasons; while the biological aspects collected were the fish size (length and weight).

Fishing boats sampled were those with millennium gillnet fishing gear of which the mesh size was between 3.7-4 inches, and they were determined randomly. Fish samples were taken by systematic random sampling which was about $10 \%$ of the total catch of the sample fishing boats. This technique is used by the researchers to take samples systematically (they were taken at the same place and within the same time interval) and in a homogeneous population. Fish sampling was done every 2 (two) weeks, in a 2-months observation.

The fish type determination used as a sample of this study was based on observations of the millennium gillnet main catches, which was the mackerel tuna (Euthynnus affinis). Meter $(\mathrm{m})$ was used as the length measurement unit, with $1 \mathrm{~mm}$ accuracy; and the weight measurement used a digital scale with 1-gram accuracy.

The technical aspects of this study used the descriptive method, which is to describe the situation or occurrence (Azwar, 2010). The relationship between fish length and weight was analyzed by the following formula model, as presented by Effendie (2002):

$$
W=a^{*} L^{b}
$$

Where: $\mathrm{W}=$ fish weight (gram); $\mathrm{L}=$ fish fork length $(\mathrm{cm}) ; \mathrm{a}$ and $\mathrm{b}=$ constants.

From this equation, we can figure out the growth pattern of fish length and weight. The value of $b$ obtained is used to determine the pattern of growth with the criteria: If $b=3$, the growth is isometric; that is the growth of length equal to the growth of weights. If $b \neq 3$, the growth pattern is allometric; that is, the value of $b<3$ is negative allometric, in which the length increase is faster than the added weight. The value of $b>3$ is positive allometric, in which the weight gain is faster than the length increment.

To test the value of $b=3$ or $b \neq 3$, a t-test (partial test) is performed; so, a hypothesis is made on the value of $b$ assuming:

$\mathrm{H}_{0}: \mathrm{b}=3$, the relationship of length and weight is isometric;

$\mathrm{H}_{1}: \mathrm{b} \neq 3$, the relationship length and weight are allometric.

The condition displaying fish corpulence with numbers is called the condition factor or the ponderal index. The condition factor $(K)$ shows the condition of the fish in terms of physical capacity for survival, reproduction, and in terms of the habitat where the fish lives (Saputra, 2009). In the metric system, the formula used in calculating the condition factor is:

$$
K=\frac{100 * W}{L^{b}}
$$

\section{RESULTS AND DISCUSSION}

Mackerel tuna caught in millennium gillnet in Pati waters and landed at Puncel has a fork length (FL) between 33.2 - $52 \mathrm{~cm}$ (average $43.012 \mathrm{~cm} \mathrm{FL),} \mathrm{and} \mathrm{median} 42.5 \mathrm{~cm}$ FL. The analysis of the correlation of length of weight to 55 tailed tuna samples produced the equation $\mathrm{W}=0.1509 \mathrm{~L} 3.0513(\mathrm{r} 2=0.9898)$ (Figure 1). After a t-test with a confidence level of $95 \%$, the value of $\mathrm{t}$-count is 0.0698 , which is smaller than the t-table $=2.0049$; this indicates that the weight increase is proportional to the growth of its length (isometric). 


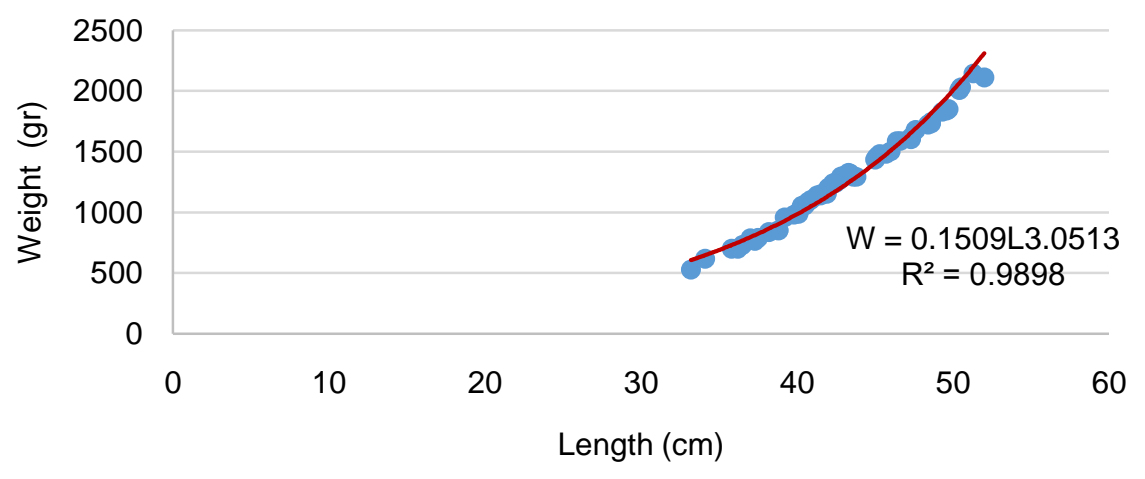

Figure 1 - Fish Length-Weight Correlation

The gillnets floated in the Java Sea and landed in Karangsong fish landing station, which is between 27-58 cm (average $45.5 \mathrm{~cm}$ ) and median $44.0 \mathrm{~cm}$. Since Pati's waters are still located in the Java Sea, the difference is insignificant. However, Chodrijah et al (2013) found that mackerel tunas captured with trawl rings and landed in Pekalongan archipelago fishing port had a range of lengths between 11.7-55.4 cm FL or an average of $34.1 \mathrm{~cm} \mathrm{FL}$. It appears that the fish caught with the millennium net is greater than those caught with trawl rings; this is because the mesh size of a millennium gillnet is 3.7-4 inch, which is more selective than that of trawl rings, which is generally around 1 inch. Moreover, the gillnets' mesh size floated at Karangsong fish landing station was around 4-5 inch and caught a long fish fork up to $58 \mathrm{~cm}$, which was longer than those caught in Pati waters.

Based on the analysis of the relationship between the weight of the mackerel tuna, the $\mathrm{W}=0.1509 \mathrm{~L} 3.0513$ equation showed that the growth pattern of the mackerel tuna caught in Pati waters had an isometric pattern with a value of $b=3(b=3.0513)$. This growth pattern is the same as the results of previous studies, even though $a$ and $b$ values are different. This different variation in the b value, according to Sparre \& Venema (1998), is caused by several factors such as temperature, salinity, food (quantity, quality, and size), gender, the stage of gonadal maturity and habitat preservation.

The mackerel tuna landed at Puncel is worth 1,613; according to Effendi (1979), the Kvalue occurs in the less flat fish. The fluctuating condition indicates the fish spawning season; in which according to Effendi (2002), the value of fish condition factors fluctuates with the size of the fish. The increase in the value of the condition factor occurs when the fish fills the gonad with sex cells and will reach its peak before spawning.

The gillnet millennium boats used in Puncel are wood-based and operated with outboard motors. These motors generally use 1 main drive engine with 24 PK power, including the Tianli and Dongfeng brands. The size of the millennium net boat at Puncel has an average length of 6.75-7 m, a width of 2.7-2.9 m, and depth of 0.9-1 m.

The millennium gillnet construction consists of a net body, top rope, buoy, buoy rope, ballast, and ballast rope. The net body's function is to vertically block the fish. The material used is 10 plies transparent white monofilament; according to Sudirman and Mallawa (2012), it is expected to have the same color as the net so that the fish do not see them as barriers. The size of one net is $120 \times 13.5$ meters with a total of 2400 horizontal mesh eyes and 140 eye vertical net eyes. Puncel fishermen carry 12-16 pieces of net in one operation depending on the size of the boat.

The net buoy used is made of Polyvinyl chloride (PVC). The distance between buoys is $40 \mathrm{~cm}$ and there are 300 pieces of buoys of in one piece of net. The buoys are made from styrofoam materials tied to a 4-meter long bamboo which has been marked with flares and lights. The pennant buoys are made of styrofoam of which the average size is $30 \times 15 \times 15 \mathrm{~cm}$, and the distance between them is $52.5 \mathrm{~m}$. The ballast used is made of cast cement in the form of a flat circle weighing 500 grams. It is installed with a distance of 15-18 m between each ballast. The specifications of millennium gillnet fishing gear operated at Puncel are presented in Figure 2. 


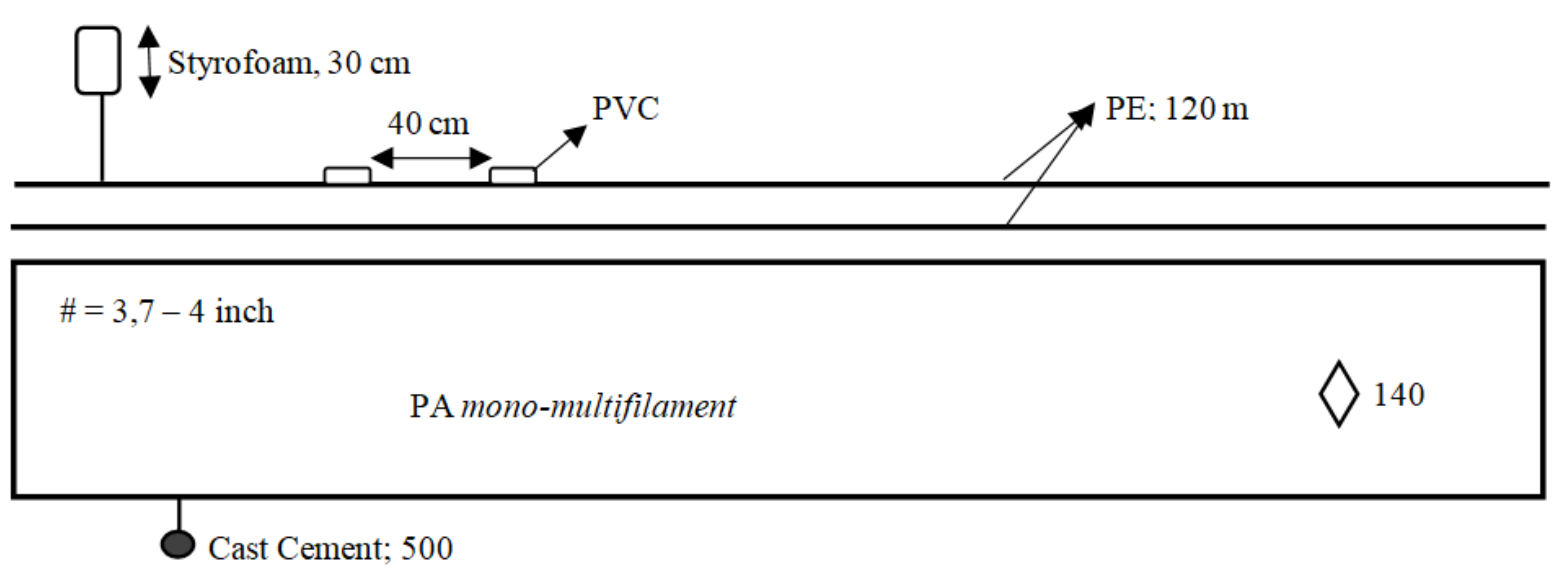

Figure 2 - The Millennium gillnet Design

The tools and supplies were prepared before going to the sea. The nets were arranged on the boat by separating the ballast and buoy to lower them easily and not to make them tangled. The fishermen left at 3:00 p.m. and arrived at the catching area within 2-3 travel hours. Fishing grounds determination commonly practiced by the fishermen today still uses traditional methods obtained from generation to generation, which is by paying attention to the brightness or color of the seawater and the calmness of the sea; this will affect the type of millennium gillnet target fish.

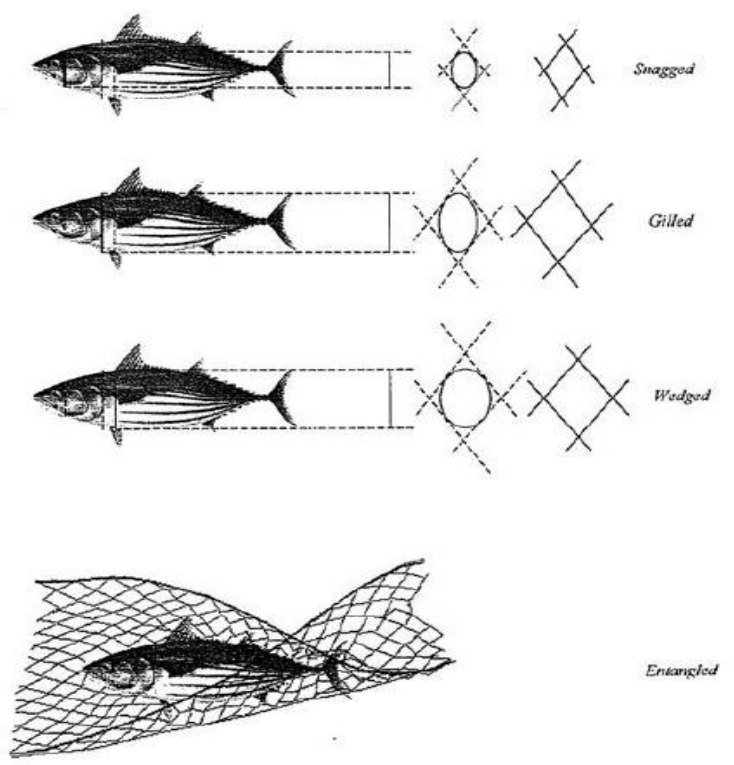

Figure 3 - The ways fish are caught with floating gillnets

The operation of gillnets is as follows:

a. Settings. After reaching the intended fishing ground, the boat stops and the setting process starts. The fishermen lower the net which begins with lowering the floating sign; then, the net is lowered from one end to the last part of the net body and tied to the boat. The setting is done in about 1 hour, depending on the length of the net being carried.

b. Immersing. The immersing process is to leave the net in the water. It takes around 34 hours. The depth level during the immersing process depends on how long the bulb rope is stretched.

c. Hauling. After leaving it for 3-4 hours, the net is lifted from the water (the hauling process) to take the catch. The process is assisted by haulers, while the fishermen take the catch one at a time. The time needed for hauling is longer than the setting because the 
fishermen need more time to release fish from net meshes and clean all the nets from dirt stuck in them; thus, the more fish they get, the longer the hauling process is.

Fish caught by millennium net are those entangled when swimming, either to move to waters suitable for their habitat or to look for food/prey. Based on the results obtained from this study, the average catches of pelagic fish or fast swimmer fish are mackerel tuna and narrow-barred Spanish mackerel.

Fish caught by gillnets were snagged, gilled, wedged and entangled. Those having a grid size equal to or smaller than the size of the net's circumference will be snagged, gilled, wedged; while those having a body circumference larger than that of the net will be entangled (Figure 3). From the results of the research, the fish were snagged and gilled in average; however, based on Masuswo and Widodo (2016), it has not been exactly known how the mackerel tuna are caught by gillnets drifting in the Java Sea because there has been no data related to it.

The quality of fish catch can decrease due to increasing time of fishing; this can be reduced through applying good storage technology, such as the hatch cooling facilities. Puncel fishermen practicing one-day fishing operation and adding ice blocks in the hold will have fish fresher than other catches.

\section{CONCLUSION}

As for the conclusion of this study, the fork length of the mackerel tuna (Euthynnus affinis) from the millennium net capture landed in Puncel fish auction houses ranged from $33.2-52 \mathrm{~cm}$, with an average $\mathrm{FL}$ of $43.012 \mathrm{~cm}$. The pattern of fish growth is isometric with the equation $\mathrm{W}=0.1509 \mathrm{~L} 3.0513(\mathrm{r} 2=0.9898)$ and the condition factor $(\mathrm{K})$ value is 1.613. From the main target fish catch, the fish were snagged and gilled on average; it can be said that the millennium net is selective in catching fish.

\section{ACKNOWLEDGMENTS}

The researchers would like to express gratitude to the Faculty of Fisheries and Marine Sciences of Diponegoro University and the fishermen group at Puncel, especially the millennium net fishermen and all of those assisting so that the research was well conducted.

\section{REFERENCES}

1. Azwar, S. 2010. Metode Penelitian. Pustaka Pelajar, Yogyakarta.

2. Badan Pusat Statistik Kabupaten Pati. 2018. Kabupaten Pati dalam Angka. Pati: Badan Pusat Statistik Kabupaten Pati.

3. Collette, B.B \& Nauen, C.E. 1983. FAO Species Catalogue. Vol. 2. Scombrids of the world. An annotated and an illustrated catalog of tunas, mackerels, bonitos and related species known to date. Rome: FAO. FAO Fish. Synop. 125(2), 137 p.

4. Chodrijah, U., Hidayat, T \& Noegroho, T. 2013. Estimasi parameter populasi ikan tongkol komo (Euthynnus affinis) di perairan Laut Jawa. BAWAL. 5(3), 167-174.

5. Effendie, M.I. (1979). Metoda Biologi Perikanan. Yogyakarta: Yayasan Agromedia.

6. Effendie, I.M. 2002. Metode Biologi Perikanan. Bogor: Yayasan Dewi Sri.

7. Masuswo, R \& Widodo, A.A. 2016. Karakteristik Biologi Ikan Tongkol Komo (Euthynnusaffinis) Yang Tertangkap Jaring Insang Hanyut Di Laut Jawa. BAWAL Vol. 8 (1) April 2016: 57-63

8. Saputra, S.W. 2009. Dinamika Populasi Ikan Berbasis Riset. Semarang: Badan Penerbit Universitas Diponegoro. ISBN 978-979-704-867-9.

9. Spare, P \& Venema, S.C. 1998. Introduction to tropical fish stock assessment. Part 1. Manual. FAO Fisheries Technical Paper. No. 306.1, Rev.2 (p. 407). Rome, FAO.

10. Sudirman \& Mallawa, A. 2012. Teknik Penangkapan Ikan. Jakarta: PT Rineka Cipta. 